\title{
Whereas an observer has nothing to do with it!
}

\author{
Emir E. Ashursky* \\ Institute for Scientific Prognosys, Kiev, Ukraine
}

\begin{abstract}
In this article, the author, as possible, subjects to a comprehensive (though mostly, it's true, critical) analysis the one-sided attempts of a number of current Western astrophysicists to somehow substantiate the well-known Fermi paradox. Is it a joke to say: in own perverted designs, some of them even go so far as to unceremoniously rearrange the cause with the effect! However, so to speak, "for greater pluralism of views", we'll along the way quote many other, much clearer and sapider opinions on this topic - right from the lips of alternatively thinking scholars (and besides - I note - with a world name!). Wherein some of them frankly assess the today stalemate uncertainty as a kind of creative stagnation; second are inclined towards the version of consumerity-driven global theoretical shift; while third directly declare that it is time for representatives of the exact sciences, obviously, to prepare for the change of the old starry paradigm to cardinally updated one. But still, without waiting for the weather by the sea (as well as just for spite the arrogant purse-proud Yankees, who, alas, do not seriously recognize our current potential capabilities, or even past truly grandiose achievements), here we will try independently to resolve some of the most controversial issues.
\end{abstract}

Keywords: proscopy - many-phase evolution - Drake equation - anthropic principle - pulsating Universe - informons - pranophytes - ontological memory -theosophical doctrine - hegemony of robots

\section{Introduction}

The freshest widely publicized successes of overseas theorists who have by guess "studied" the first seconds after the Big Bang through orbiting telescopes and nuclear colliders, along with pride in modern world science, cannot but evoke in you and me a bit of sound skepticism about their activities. For such a zero retropolation often, alas, contradicts many accepted logical postulates. In particular, if long-term forecasts are anyway built usually thanks to the sufficient availability of $100 \%$ proven archived facts, then it is still not entirely clear, what speculative "peeping" into pre-human history can be based on. And from here - you, as it were, shouldn't be extra surprised by the abundance of all kinds of false moves and other semantic absurdities (from the model of the Cold Big Bang - to the ever-memorable torsion fields) by the spontaneous witnesses of which most of us had a chance to become.

In this regard, I will give a couple of illustrative examples. In 2017, Nikolai Kardashev, director of the FIAN Astrospace Center (Moscow), said that, in his opinion, all highly developed civilizations had long since left our Universe, having moved to other areas of the Multiversum that are more suitable for them. True, it is not so difficult to guess the oblique cause for such a rather strange unscientific statement for an academician. The fact is that at the very beginning of his research career, Nikolai Semyonovich often assured his colleagues in all seriousness that in the near future he had real plans to meet, and perhaps even personally make contacts with someone of the intelligent alien inhabitants. However, as soon as his this-worldly path began gradually but steadily to approach its eternal implacable finale, the gray-haired metropolitan "ex-dreamer" was already forced nolens-volens to look for any options of more or less decorous tactical retreat.

\footnotetext{
*e.ashursky@gmail.com
} 
Although in this sense, his faithful deputy at the institute Igor Novikov, who was carried away back in the mid-1980s, frankly, with a very, very dubious idea of creating a time machine, turned out to be by no means more far-sighted than his boss. Much has already been said about the apparent delusionality of such baseless fantasies, which contradict all recognized natural science canons (especially with regard to chrono-voyages into the past). However, the author is going to share own interesting views and thoughts on this matter with the readers of ComBAO in more detail already in the next (autumn) issue of the magazine. But nevertheless, Igor Dmitrievich himself is still to no avail toiling with his inflamed "idée fixe" to this day...

So in general, presumably, it was not in vain that the ancient Latins used to say: «Errare humanum est, stultum est in errore perseverare». For in the end, a similar fate has not passed the greatest genius of Soviet astronomy V.A. Ambartsumyan either. Particularly, in 1958, at the traditional Brussels conference "Solvay" in physics, he read one of his most famous reports, publicly declaring for the first time that "enormous explosions take place in galactic nuclei and as a result a huge amount of mass is expelled. In addition, they (galactic nuclei) must contain bodies of unknown nature". Thus, he gave, in essence, a creative impetus to a new science - the theory of galactic evolution. And everything would be fine, but only in his subsequent works, Viktor Amazaspovich, having apparently succumbed to all kinds of fashionable then illusory-deceptive hypotheses, presented own position in a slightly different way. To wit: supposedly such smoked-bluish jets are nothing more than spontaneous intrusions of matter from parallel cosmic reality. Although in fact it is now generally accepted that this is most likely due to the interaction of the magnetic field with the accretion disk around the black hole (well or, as a quite valid option, the very massive neutron star).

By the by, it was no coincidence that we took the liberty of making here this brief (but, I hope, useful) excursion into the times of the formation of the newest progressive knowledge about space. For in this article, the author, as possible, subjects to a comprehensive (though mostly, it's true, critical) analysis the one-sided attempts of a number of current Western astrophysicists to somehow substantiate the well-known Fermi paradox. Is it a joke to say: in their perverted designs, some of them even go so far as to unceremoniously rearrange the cause with the effect!

However along the way, so to speak, "for greater pluralism of views", we will quote many other, much clearer and sapider opinions on this topic - right from the lips of alternatively thinking scholars (and besides - I'll note - with a world name!). Wherein some of them frankly assess the today stalemate uncertainty as a kind of creative stagnation; second are inclined towards the version of consumeritydriven global theoretical shift; while third directly declare that it is time for representatives of the exact sciences, obviously, to prepare for the change of the old starry paradigm to cardinally updated one. But still, without waiting for the weather by the sea (and also just for spite the arrogant purseproud Yankees, who, alas, do not seriously recognize our current potential capabilities, or even past truly grandiose achievements), here we will try independently to resolve some of the most controversial issues.

\section{Whereas an observer is surely far-fetched here by ears.}

It's no secret that the amateurish naivety of the so-called anthropic principle is now being criticized by many competent and widely known in the world specialists. Although, in fact, in the model of the "pulsating Universe" (as well as in L. Smolin's very just relevant today evolutionary hypothesis), the choice of the initial free parameters is obviously not accidental. First, it can be assumed that they - as inviolable reference samples - are entirely passed from generation to generation. Secondly, even if they are formed anew at each next Bang, it is due to having some kind of "through" ontological memory. But even with the culling away both of these facultative guesses, as a decisive unshakable argument against the imaginary anthropophilicity of our existence is what in absolutely any Universe there must present subtle demigods \& angels (pranophytes) as well as, apparently, the smallest fragments of the mind (informons). This, of course, also applies to those cases when the self-assembly of heavy elements or molecules (and hence, the habitual life for us) would turn out to be too energy-intensive and de-facto unpromising from the astrophysical point of view.

By the way, actually one can imagine in theory 3 principled dynamic schemes of universe: 
a) a kind of swing "from energy (Will) $\Longrightarrow$ to information (Reason) and back";

b) continuous experiments or even improvisations of Will itself (let's note that the old theosophical teaching about the previously existed 5 discarnate races also fits into here);

c) and finally, as if independently of them, a fashionable freshly-baked hypothesis about our being as a computer simulation of the physical world can be considered either (moreover, in this case, bits and bytes well familiar to IT-specialists become already the main source of interaction of all real-virtual objects).

In the first paragraph, predicting events (proscopy) is possible due to a clear step-by-step repeatability of history; and in the second - through the management of the events relevant for the Will. As for the semi-fantastic idea of parallel worlds (or, say, multidimensional space), it doesn't, apparently, jump beyond this framework, and only brings some own colorful variety to the overall picture.

By the way, the seeming polarity of interests of Reason and Will is actually sometimes felt, perhaps, except that in the socio-historical plane. At the rest they are everywhere going side by side, as if complementing each other, and moreover under the general supremacy (for now, at least) of Reason. That's why we can oppose them each other on the scale of the Universe (and even then - as one of several permissible options) only in terms of time parameters: from the energy of saturated but structureless chaos - to an extremely structured but cold lifeless Cosmos. And just at this finishing segment, due to the critical shortage of energetic resources, the transition from the current living civilization to the hegemony of robots seems to be quite real.

\section{And what is proposed by the author instead?}

So, what are the logical conclusions from this? Well, first of all, the fact that the "strong anthropic principle" on the version of J. A. Wheeler ("Observers are necessary to bring the Universe into being"), despite even its wit and ostentatious elegance, is actually a rather trivial, i.e. doesn't give researchers any practical benefit. As for the "weak" (a little earlier proposed by our countryman G. M. Idlis in such formulation: "We are observing a deliberately not an arbitrary region of the Universe, but the one whose special structure made it suitable for the emergence and development of life") then here, alas, things are much worse. Not only is it, already inherently imbued with sophistry (having unceremoniously reshuffled cause and effect) but also does not correspond at all to the reality around us. Because for any corpuscular parameters, the probability of the emergence of intelligent life (and along with it - of an observer himself) remains all the same high enough! Well, perhaps only, however, not in vacuum space; and of course, not right there away - as if by a fleeting whim of a goldfish but at least after a few billion years...

Nevertheless some are trying to appeal here to the notorious Drake equation:

$$
N=R \cdot f_{p} \cdot n_{e} \cdot f_{l} \cdot f_{i} \cdot f_{c} \cdot L
$$

They say, if even by the most moderate standards, in our galaxy should be 10 highly developed extraterrestrial cultures but there is not a single one of them so far - then, in their opinion, it means that the uniqueness of a formal observer is something for granted. While in reality, the last circumstance can, perhaps, testify only to the fact trite Laplace-Cartesian explanation here, alas, does not work. That is, more specifically, this indicates the etiological complexity of the origin of civilizations associated with the nonlinearity of the paths "from inanimate to living" (which, as it were, is confirmed by the spread version about the 5 races that preceded us).

In general, comparing H. P. Blavatsky's theory of the root races with modern biologists' evolutionary tree, one involuntarily comes to the conclusion that the former quite might serve as a kind of well-adapted soil for the normal "growth" of the latter. In other words, at first for a pretty long time the primary bricks of organized matter (in the form of stable atoms and complex polymer molecules) took shape painstakingly from the ether, the astral, the mental body as well as proton substrate, and then everything already continued according to the familiar school scenario. 
But, incidentally, only a rough simplified picture of earthly evolution was still given here. Since, in fact, both of these processes went on almost simultaneously with each other; however at the preparatory stage, the laws of theosophy (or, if you like, astrophysics) "ruled" in it, though hereinafter they have already become predominantly of biological nature. In this regard, the emergence of a habitual phenomenon of life can be somehow discussed, perhaps, from the moment of a successful mutually beneficial synthesis of the mental sheath (responsible, as known, for ancestral memory) with the immanent sensitivity of organic rings.

Thus, here we - in contrast to the obviously far-fetched anthropic - come to the formulation of another principle, much more important for science. Its essence is that the Universe at this stage is being ordered in a qualitative aspect, disordering simultaneously in a quantitative (thermal) one. Moreover, this fundamental property should, apparently, apply to all laws of thermodynamics (and in particular, the second). Although the same concerns to synergetics either - contrary to what I. Prigogine imagined (supposedly, individual fluctuations arise against the background of a general increase in entropy, but all this is only in some limited space).

So, most likely, disordering goes along the energetic vector, and self-regulation along the informational one. But this dependence, however, is not linear, since a developed intellect creates new algorithmic products much easier and faster - without high energy consumptions (when compared with that was at the dawn of Universe's formation). And hence, the dilemma about "what namely (elementary micro-regulating or machine-human macro-intelligence) the current algorithms are spawned by" is no longer almost meaningful, since any modern intelligence, in turn, is a product of the streamlining. That is, the vast majority of today laws of physics, chemistry and biology (and especially the firsts of them) are the result of the action of self-organizing processes, for they all, in one way or another, are associated with orderly movement!

\section{Well, and what do world luminaries think about that?}

And finally, as promised, we will cite some of the brightest and original (though sometimes, it is true, quite sharp) opinions of popular writers and recognized luminaries of academic science, including even last year's Nobel laureates.

So, the anthropic principle, as we found out, inherently presupposes not only suitable primary conditions, but a precise and adequate adjustment of a number of necessary parameters. Although at the same time, according to the famous British physicist sir Roger Penrose, it could hardly serve as the main driving force behind externally directed evolution: after all, consciousness is, in general, only a kind of handy tool for natural selection.

And according to the editor-in-chief of "Skeptic" magazine Michael Shermer, rejecting the belief in a single carbon form of life, one can conclude that in reality it is we who are perfectly and accurately tuned to the Universe, and not vice versa. And even if it is difficult for us to fully understand how exactly physical phenomena correlate with the earth mind, it still "supposes" about this quite differently!

For his part, the legendary Polish science fiction writer Stanislaw Lem emphasizes that where per definition is empty, there are no corresponding reason to talk about some personality with own worldview. And, besides, the Universe cannot be accused of deliberate intent, which means that the very existence of an abstract observer is not obligate too. In other words, it develops the way it wants - and no special higher sense can stand behind that.

And here it should also be borne in mind that we are usually tend to find correlations wherever, as seems to us, it could not do without a prior conscious adjustment or "garbling the cards". One such case is the conditional analogy with the firing squad (on the illustrative example of the Canadian philosopher John Leslie) - when a prisoner, who was about to expect death, suddenly remains unharmed, constantly being puzzled after that by persistent obsession: didn't this company of riflemen deliberately missed? 
In turn, the European authority №1 on neural networks Jürgen Schmidhuber points out that the anthropic principle does not allow to predict anything truly useful and important for us or to answer at least some topical questions of being.

So, taking into account all these characteristics, it can even be equated to the main working tool of psychologists. Well and if someone is still not quite in the know, let me remind you: with no matter how severe personal grief this or that client turns to such "mental savers", a real professional psychologist will first of all try to assure him, supposedly all that has happened is in fact the greatest attainable good and almost heavenly happiness. Because in any alternative scenario, the new psychologically calculated situation would certainly be a hundred times worse!

Let's now turn to the "weak anthropic principle". From its definition directly, in particular, it follows, that somewhere around us there may well be other material universes (but already with different settings). And in them, moreover, intelligent life is practically no longer capable of originating. But if one talks about the multidimensional quantum mechanical interpretation, then (according to an emeritus professor of humanities John Earman) we do not yet have any even vague guesses about the very mechanism of splitting of that hypothetical proto-Universe. And, of course, there is no information about where, when and for what reason such could have happened at all. That's why at this stage of our planetary development, we have no right to assert competently about the plurality of worlds.

And finally, it should be added that some deeply religious scholars (for example, member of the Royal Society rev. John Polkinghorne) use the anthropic principle as another convincing proof of God-presence. I.e. that supposedly it was the Lord who created such a subtle cosmic setting which allowed an intelligent earthly observer to exist. No wonder that, as the famous Christian apologist and neoplatonist William Craig notes, in the midst of heated discussions on the anthropic principle, the boundaries between physics and philosophy are becoming already rather blurred.

However, the argument about man as the crown of divine creation is intuitive one: so it cannot yet, by and large, be confirmed or refuted. After all, de-facto you and I are only a small insignificant piece of the Universe, the sudden disappearance of which it will not even notice; and the notorious anthropic principle is just a mistake of the player, who clearly, alas, overestimated his role.

\section{References}

1. В. А. Амбарцумян: «Философские вопросы науки о вселенной»- Ереван, 1973 г.

2. W. Ambartsumian: "Philosophische Probleme der modernen Kosmologie."- Berlin, 1965.

3. Hynek J. Allen \& Vallee Jacques: "The Edge of Reality". - Chicago: Henry Regnery. 1975.

4. К. И.Чурюмов, А.Ф.Пугач: «Небо без чудес»- Киев, «Политиздат Украины», 1987г.

5. Станислав Лем: «Одиноки ли мы в космосе?»- М., журнал «Знание - сила» № 7, 1977 г.

6. Э. Э. Ашшурский: «Сквозь призму философского анализа» //Киев, изд. «Пам'ятки України», 1998 г.

7. Э. Э. Ашшурский: «Опыт философского осмысления противоречий современной науки» // Киев, изд. «Эсперанца», 1994 г.

8. И. Р. Пригожин, И. Стенгерс - «Порядок из хаоса: Новый диалог человека с Природой». - М.: Прогресс, 1986. - 431 с.

9. Г. В. Чефранов: «Бог. Вселенная. Человек»//Таганрог, изд. ТРТИ, 1992 г.

10. Наталия Лескова: «То, что мы делаем, - это впервые» (интервью с Н.С.Кардашевым) // журнал «Наука и жизнь». - № 11 за 2017.г., с. 14-19.

11.Э. Э. Ашшурский: «Философия в поисках и находках»//Киев, изд. «Эсперанца», 1997 г. 